\title{
Top-down and bottom-up stabilizing mechanisms in eelgrass meadows differentially affected by coastal upwelling
}

\author{
Pablo Jorgensen $^{1, *}$, Silvia E. Ibarra-Obando ${ }^{1}$, José D. Carriquiry ${ }^{2}$ \\ ${ }^{1}$ Centro de Investigación Científica y de Educación Superior de Ensenada (CICESE), Carretera Tijuana-Ensenada, Km. 107, \\ 22860 Ensenada, Baja California, Mexico \\ ${ }^{2}$ Instituto de Investigaciones Oceanológicas (IIO-UABC), Universidad Autónoma de Baja California, 22860 Ensenada, \\ Baja California, Mexico
}

\begin{abstract}
Trophic cascades usually regulate structure and dynamics of valuable benthic vegetation communities (e.g. kelp forests, salt marshes), resulting in alternating high and low abundances from predators at the highest level, down through herbivores, to basal producers at the lowest trophic level. While herbivores may have direct strong negative effects on kelp and salt marsh vegetation, grazing invertebrates (mesograzers) within seagrass meadows consume and thus control the biomass of opportunistic epiphyte algae that can outcompete seagrasses for light. Small fish predators, however, may control mesograzer abundances, thus releasing epiphytes from grazing pressure, with resultant widespread losses of seagrasses under eutrophic conditions. In order to assess whether trophic cascades operate in seagrass systems, we compared patterns of abundance and composition of the benthic vegetation community, the associated epifaunal invertebrates, and their predators in eelgrass meadows distributed across a natural gradient of algal productivity. Within this gradient we selected and sampled in summer and winter 3 eelgrass meadows differentially affected by strong coastal upwelling. High mesograzer abundance repeatedly coincided with low epiphyte biomass, emphasizing top-down control of epiphytes, despite high nutrient availability. Consumption of live eelgrass tissue by mesograzers was potentially important at the lower end of the productivity gradient. Alternating patterns of abundances between successive trophic levels under intermediate and high productivity conditions suggest that small predator abundances may ultimately govern the success of eelgrass in eutrophic meadows. When pipefish were abundant and eelgrass complexity was low, patterns were consistent with a destabilizing trophic cascade. Evidence supporting a trophic cascade dynamic from small fish through to epiphytes may indicate susceptibility of eelgrass systems to higher order interactions.
\end{abstract}

KEY WORDS: Seagrass · Zostera marina · Trophic cascade · Epifauna · Herbivory · Coastal upwelling · Baja California

Resale or republication not permitted without written consent of the publisher

\section{INTRODUCTION}

The structure and dynamics of benthic aquatic communities can be strongly regulated by consumers in the food web, i.e. 'top-down control' (Shurin et al. 2002). Top-down effects are most obvious when the inherent complexity of food webs can be simplified into interaction chains with a distinctive number of trophic levels, with predators substantially altering the distribution of basal species biomass throughout the entire system. Food web structure is sometimes re- duced to only 3 interactive trophic levels (i.e. predators, herbivores and primary producers) to explain significant impacts on ecosystem processes, e.g. productivity, or energy transfer (Hairston \& Hairston 1993). Under this simplified tri-trophic structure, predators indirectly benefit primary producers by limiting the densities of herbivores through a 'trophic cascade'. Consequently, trophic cascades result in alternating high and low abundances from top predators (high abundance), through herbivores (low abundance), to basal producers (high abundance). 
The trophic cascade model can successfully describe community dynamics in marine and estuarine benthos where foundation or habitat forming species provide structure to entire species assemblages (e.g. Estes \& Duggins 1995, Silliman \& Bertness 2002). Usually, foundation species in aquatic systems are indirectly, but strongly linked to their associated species by a stabilizing tri-trophic cascade. Therefore, the function and persistence of these aquatic systems depend on a facultative mutualistic relationship between the foundation species and their associated predators (Hay et al. 2004). For example, kelp forest development in Alaska has been associated with the recovery of sea-otters and large reductions in herbivorous sea urchin abundances (Estes \& Duggins 1995). High levels of primary production in salt marsh communities were found to be indirectly facilitated by blue crabs and other predators controlling grazing snail densities (Silliman \& Bertness 2002). In turn, both kelps and salt marsh vegetation provide biogenic structure and high production of persistent prey that increase local carrying capacity and stability of predator populations (Hay et al. 2004).

As in the cases of kelp forests and salt marshes, seagrass meadows are a foundation vegetation that provide substratum, food and refuge for a rich association of fauna and flora (Hay et al. 2004). While herbivores have direct strong negative effects on kelp and marsh vegetation (Estes \& Duggins 1995, Silliman \& Bertness 2002), small invertebrates, such as amphipods, isopods and gastropods (i.e. mesograzers), usually have a mutualistic relationship with seagrasses (Hay et al. 2004, Valentine \& Duffy 2006). Structurally complex seagrass habitat diminishes predation pressure on epifauna, promoting enhanced survival of mesograzers (reviewed by Heck \& Orth 2006). In turn, the feeding activities of dense and diverse mesograzer populations control the biomass of opportunistic epiphytic algae that are able to outcompete seagrasses for light (Heck et al. 2000, and references therein). Hence, epifaunal abundance, biomass and diversity are frequently positively related to macrophyte surface area or biomass (Attrill et al. 2000). However, the interaction between seagrasses and mesograzers is conditional and can change from mutual to neutral or antagonist, depending on resource supply for primary consumers (Hay et al. 2004, Valentine \& Duffy 2006). When low nutrient concentration limits their development, epiphytic algae can become scarce, and mesograzers will not enhance seagrass growth. Indeed, the grazers may, under these circumstances, consume living seagrass tissue (references in Hay et al. 2004).

Recent reviews of the role of trophic interactions in modern seagrass meadow function emphasise the need for a more comprehensive understanding of the relative importance of resource supply, consumer pres- sure, and their interactions in regulating the health of seagrasses (Hughes et al. 2004, Heck \& Orth 2006, Heck \& Valentine 2006, Valentine \& Duffy 2006). In particular, where nutrient loading selects for fastgrowing algae, natural or anthropogenic processes that negatively affect mesograzer populations may indirectly reduce seagrass meadow stability (Heck et al. 2000). In this sense, 'the importance of predation in influencing assemblage structure of mesograzers, and their cascading impacts on primary producers in seagrass beds, remain an important challenge for future research' (Valentine \& Duffy 2006). Small predators, mainly those well adapted to forage within the tangle of seagrass leaves (e.g. shrimps, pipefish), may exert a strong impact on mesograzers (Heck \& Orth 2006), and indirectly influence the outcome of competitive interactions between seagrasses and opportunistic algae. Such a trophic cascade may be common in relatively low-diversity temperate seagrass meadows where there is reduced presence of predator-resistant taxa capable of buffering top-down control, and thus a stronger propagation of indirect effects from predators to plants (Valentine \& Duffy 2006).

Trophic cascades have not yet been demonstrated conclusively in seagrass meadows (Duffy 2006). However, most empirical descriptions of seagrass dynamics come from short-term, small-scale laboratory and mesocosm experiments that have at most examined interactions between 3 functional groups (mesograzers, epiphytes, and seagrasses) (Hughes et al. 2004, Valentine \& Duffy 2006). Very few studies have included small predators, mesograzers, epiphytes, and seagrass simultaneously (e.g. Heck et al. 2000, Duffy et al. 2005). Even in these studies, potential predator effects were likely underestimated because the species were considered one at a time, while in the sea, small predators are present in a diverse fauna of small fish, decapods and other invertebrates that feed on mesograzers. Increasing diversity within a trophic level often increases its relative influence on ecosystem functioning, as diverse assemblages are more likely to contain a strong interactor species (the 'sampling effect'). Diverse assemblages have species with a larger range of traits, allowing for a more efficient exploitation of available resources ('niche complementarity') (see Duffy 2006, and references therein).

Alternative approaches to earlier works, including comparative studies and natural experiments are urgently needed to evaluate the mechanisms structuring seagrass communities at more realistic and broader scales (i.e. ecosystem scale) (Duffy 2006, Valentine \& Duffy 2006). Hence, in this study we took advantage of a natural gradient of algal productivity to assess potential trophic cascade dynamics in seagrass ecosystems under variable light and nutrient conditions. The oc- 
currence of trophic cascades was inferred from patterns of abundance and composition of the benthic vegetation community, its associated epifaunal invertebrates and their predators in eelgrass (Zostera marina) meadows arrayed across a natural productivity gradient. Although the approach does not allow us to categorically identify the causal mechanisms that structure the seagrass communities studied, we were able to construct robust postulates for the main processes affecting eelgrass dynamics and to identify potential key taxa governing these processes.

The alternation of high and low biomasses (or other measures of abundance) between successive trophic levels, from small fish through to epiphytes, would suggest the likelihood of a trophic cascade operating in eelgrass meadows. The outcome of the trophic cascade on eelgrass health will depend on nutrient availability for opportunistic algae and on the number of strong interacting trophic levels. If mesograzer abundance is regulated by the density of small fish predators, then grazing pressure is less likely to control epiphytes under high nutrient availability and abundance of predators, and the vegetation community will exhibit stress symptoms deriving from reduced photosynthesis, e.g. lower eelgrass density, biomass and productivity. With low fish abundance, numerous mesograzers should control opportunistic algae, and enhance eelgrass biomass and productivity by removing epiphytes, thus mitigating the negative effects of eutrophication. At the lower end of the algal productivity gradient, however, uncontrolled mesograzer abundance is predicted to be inversely related to eelgrass biomass and productivity, indicating a shift to direct consumption on eelgrass tissue in response to limited epiphyte biomass. In either situation, if mesograzers abundance is unaffected by the number of small fish predators, then eutrophication may have little impact on epiphyte biomass as grazer populations will adjust their density to match resource availability.

\section{MATERIALS AND METHODS}

Study area. San Quintin Bay is a relatively undisturbed coastal lagoon located on the northwest coast of the Baja California Peninsula, about $300 \mathrm{~km}$ south of the Mexico-USA border (Fig. 1). Tides are semidiurnal with mean amplitude of $1.6 \mathrm{~m}$ (Ibarra-Obando et al. 2004). Surface and groundwater flows are usually limited, with most external physical and biogeochemical forcing from the neighboring ocean (Camacho-Ibar et al. 2003). San Quintin Bay can be divided into 3 distinct environmental subsystems (Fig. 1) (Camacho-Ibar et al. 2003): SQ (Bahia San Quintin) and BF (Bahia Falsa) are the eastern and western arms, respectively, while
BY (Base Y) is the region near the mouth of the bay. These subsystems are affected differently by conditions in the oceanic region: BY and BF are both well flushed throughout the year (water exchange times, $\tau=\sim 2 \mathrm{~d}$, and 4 to $6 \mathrm{~d}$, respectively) compared to SQ ( $\tau=11$ to $45 \mathrm{~d}$ ) (Camacho-Ibar et al. 2003). The major axis of BF has a northwest to southeast orientation. The dominant winds that promote coastal upwelling are northwesterlies, hence nutrient rich water enters the mouth of the bay.

Upwelling events are persistent throughout the year but stronger during spring and summer. Off San Quintin Bay, upwelling events advect nitrate rich ocean water into the lagoon, promoting high phytoplankton (>40 $\mathrm{mg} \mathrm{C} \mathrm{m}^{-3} \mathrm{~h}^{-1}$ ) and macroalgal productivity and biomass (reviewed by Alvarez-Borrego 2004). Phytoplankton abundance and productivity decrease from BY toward the inner parts of the lagoon, and may be between 3- and 10-fold lower than at the mouth. There is usually higher phytoplankton biomass and productivity in BF than in SQ. Conversely, eelgrass Zostera marina mean subsystem productivity is

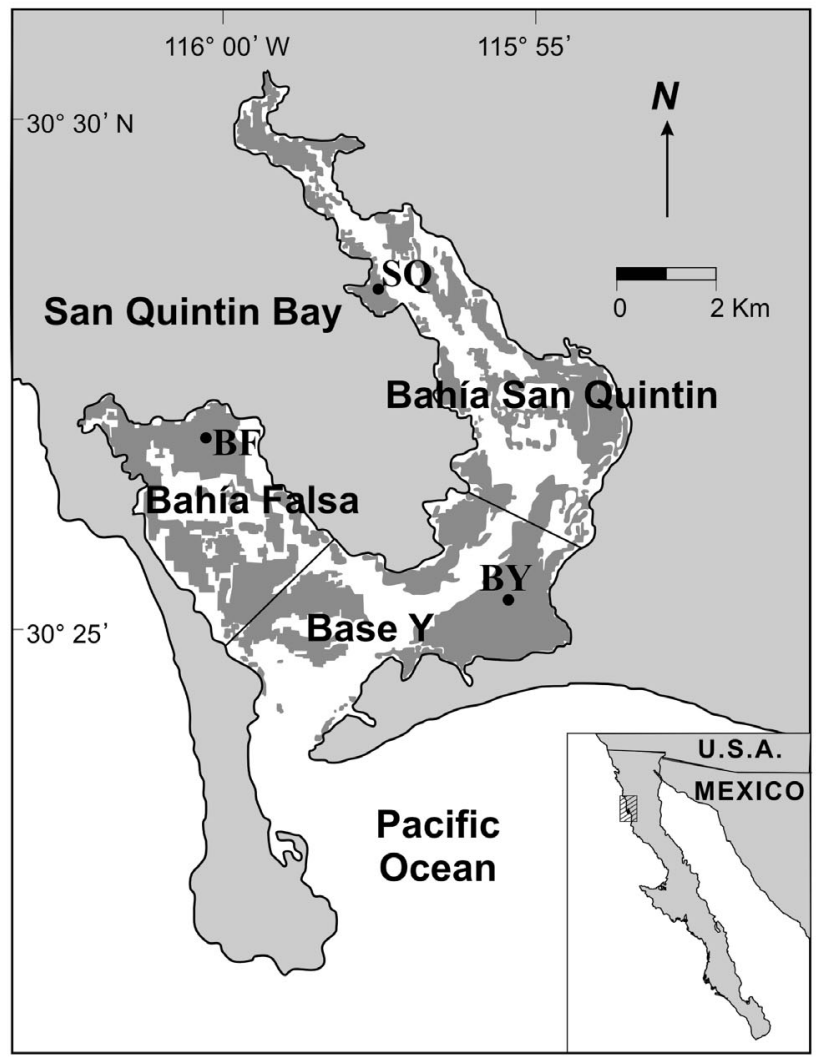

Fig. 1. Geographic location of San Quintin Bay in Baja California Peninsula (Mexico) showing the distribution of eelgrass meadows. Map adapted from a Landsat-5 TM image taken on January 19, 1994. Zostera marina meadows sampled were: $\mathrm{BY}$, the region near the mouth of the coastal lagoon; BF, in the west arm; and $\mathrm{SQ}_{1}$ in the east arm 
larger in SQ and BF than at BY (Camacho-Ibar et al. 2003). These eelgrass productivity estimates were based on eelgrass cover differences among subsystems, assuming no spatial differences in $Z$. marina growth rates.

Eelgrass meadows are the most abundant benthic habitat in San Quintin Bay, covering $46 \%$ of the substratum (Ward et al. 2003). They are responsible for $\sim 80 \%$ of the lagoon's benthic metabolism (IbarraObando et al. 2004). Drifting macroalgal biomass in Zostera marina meadows may surpass eelgrass aboveground biomass during late summer (Ibarra-Obando \& Aguilar-Rosas 1985). Benthic diatoms may heavily epiphytize eelgrass blades (Siqueiros-Beltrones et al. 1985). Salt-marsh vegetation and sediment microalgae contribute less than $15 \%$ to the total productivity in the system (Ibarra-Obando et al. 2004). Epifaunal abundance and diversity are positively related to eelgrass aboveground biomass and peak during late summer. The amphipods Erichtonius brasiliensis and Hyale frequens and the polychaete Platynereis bicanaliculata form a distinctive group of species clearly linked to the presence of Z. marina (Quiroz-Vázquez et al. 2005, and references therein). Most previous studies of eelgrass and its associated species in the region were based on the analysis of single meadows within the Bahía Falsa arm. Our study is the first to provide information on spatial differences in eelgrass community structure related to coastal upwelling influence.

Sampling design. Three meadows, each over $1 \mathrm{~km}^{2}$ in area and with monospecific eelgrass canopy, were sampled in San Quintin Bay. Each meadow was located in one of 3 areas differentially affected by coastal upwelling (Camacho-Ibar et al. 2003) (Fig. 1). Meadows were selected along a phytoplankton productivity gradient to explore potential interactions between benthic flora and fauna, rather than to characterize spatial or temporal community trends. Environmental factors combinations in the BY meadow had the potential to promote high productivity conditions for opportunistic algae (i.e. high water column nitrate concentrations, phytoplankton advection), while BF and SQ meadows had intermediate and low productivity conditions, respectively. All seagrass meadows selected had high and continuous Zostera marina cover. Dense drifting Ulva expansa mats occurred only within BY and BF meadows. All 3 meadows were sampled during strong (summer: S) and weak (winter: W) upwelling seasons. Selected meadows were located in the transition area between the low intertidal and the subtidal zones (-0.2 m MLLW to -0.5 m MLLW), where light may be strongly attenuated by physical (tidal currents, wind waves) and biological processes (algal blooms). Tidal current strength decreases from BY toward the inner arms, while wind waves inducing water turbidity are smaller at $\mathrm{SQ}$ than at $\mathrm{BF}$, as the east arm is less exposed to wind stress (Alvarez-Borrego 2004). Wind induced turbulence was likely more intense during the winter samplings (Pacific Fisheries Environmental Laboratory, NOAA: http://upwell.pfeg. noaa.gov, Jorgensen pers. obs.).

Water column: Physico-chemical properties of the water column were characterized in each meadow during spring tides in summer 2001 and winter 2002. Three semidiurnal time-series samplings were carried out on random dates covering the period of lowest tides between July 31 and August 6 (summer), and three between March 10 and 17 (winter). One 21 surface water sample was collected every $3 \mathrm{~h}$ and stored in ice until filtration. Samples were later analyzed for nutrients and seston. Simultaneously, surface temperature $\left( \pm 0.1^{\circ} \mathrm{C}\right)$, salinity $( \pm 1), \mathrm{pH}( \pm 0.01)$, dissolved oxygen concentrations $\left( \pm 0.01 \mathrm{mg} \mathrm{l}^{-1}\right)$, and incident and submarine photosynthetically active radiation (PAR: measured with a cosine-corrected sensor attached to LI-COR radiometer) were measured in situ. The depth averaged irradiance attenuation coefficient was estimated for each meadow by determining irradiance just below the surface and above the Zostera marina leaf canopy between 10:00 and 15:00 h. In the laboratory, samples for nutrient and seston analyses were filtered through pre-combusted and pre-weighed Whatman GF/F filters. Filters and nutrient samples were immediately frozen at $-20^{\circ} \mathrm{C}$ until analysis. Dissolved inorganic (reactive) phosphate, nitrate plus nitrite, ammonium and silicate were determined using an automated analyzer (Skalar). Filters were freeze-dried and re-weighed to determine seston concentrations.

Nekton: Vagile secondary consumers were sampled during daylight hours in shallow subtidal continuous eelgrass meadows adjacent to each study site, to avoid perturbations of simultaneous experiments. Three 5 min tows were made with a $1.6 \mathrm{~m}$ wide, $0.4 \mathrm{~m}$ high beam trawl (3 mm mesh) at each location during each sampling season, between July 19-21, 2001 (summer), and February 24-26, 2002 (winter). Tows followed a circular trajectory at $\sim 1.0$ knot. All fish and decapods were stored in ice immediately after capture. Animals were preserved in a $4 \%$ formaldehyde buffered seawater solution, identified, and counted.

Benthos: Benthic samples were collected during the lowest tides in each season (water depth $\leq 30 \mathrm{~cm}$ ). Two surveys were performed during each sampling period; summer: July 20-22 $\left(\mathrm{S}_{1}\right)$ and August 17-19 $\left(\mathrm{S}_{2}\right), 2001$; winter: February 23-25 $\left(\mathrm{W}_{1}\right)$ and March 25-29 $\left(\mathrm{W}_{2}\right)$, 2002. During the first survey of each sampling season $\left(\mathrm{S}_{1}\right.$ and $\left.\mathrm{W}_{1}\right)$ we haphazardly selected 8 points separated by several meters in each meadow. A $3 \mathrm{~mm}$ mesh nylon cylindrical fence $(40 \mathrm{~cm}$ internal diameter and $60 \mathrm{~cm}$ height, open at both ends, with the downward 
end encircled with an attached sharp steel circular strip) was used to delimit the sampling area at each selected point. For half of the 8 replicates, we marked 10 vegetative shoots within restricted areas inside the mesh cylinders, and these shoots were used to estimate growth of Zostera marina growth. Every shoot was marked following standard leaf marking techniques (Short \& Duarte 2002).

In each of the 4 remaining sampling points selected in $\mathrm{S}_{1}$ and $\mathrm{W}_{1}$ we carefully enclosed the shoots of a $40 \mathrm{~cm}$ diameter section of meadow inside the mesh sampler, preventing egress of organisms. Three sediment cores (13 $\mathrm{cm}^{2}$ by $5 \mathrm{~cm}$ deep) were extracted and pooled, stored in ice and then used for organic matter content analysis. Ten vegetative eelgrass shoots for leaf morphometric analysis and epiphyte biomass quantification were collected by carefully digging out the plants from below the substratum. The rest of the shoots and their attached belowground material and macroalgal thalli, if present, were collected by hand and stored. Finally, a $3 \mathrm{~mm}$ mesh scoop net was gently slid underneath the surface sediment and swept through the water column to ensure that no epifauna inside the mesh cylinder fence remained. Live and dead plant fragments $>3 \mathrm{~mm}$ were also collected and stored. During the second surveys $\left(\mathrm{S}_{2}\right.$ and $\left.\mathrm{W}_{2}\right)$, we repeated the sampling procedure on the 4 sample units in which we had previously marked the eelgrass shoots for aboveground production estimation.

In the laboratory, samples for sediment organic matter quantification were sieved through a $3 \mathrm{~mm}$ mesh, and immediately frozen at $-20^{\circ} \mathrm{C}$. Later they were freeze-dried at $-50^{\circ} \mathrm{C}$, ground, and weighed. Percent organic matter (POM) content was calculated as overnight loss during ignition at $550^{\circ} \mathrm{C}$. Total leaf length, width, and epiphyte biomass were estimated from 6 randomly selected vegetative shoots per sample, following procedures described by Poumian-Tapia \& Ibarra-Obando (1999). Seagrass growth, measured in units of leaf length and mass, was determined from 3 randomly selected shoots within each sampling unit following standard methods (Short \& Duarte 2002).

Macrophytes, associated fauna, and detritus samples were separated in different fractions. All vegetative and reproductive shoots present were sorted to calculate their density. Fractions were: (1) leaves (2) sheaths (3) reproductive shoots (4) roots and rhizomes (5) coarse detritus (mainly dead eelgrass plus benthic fauna), and (6) macroalgae. All fractions were rinsed with distilled water and their dry masses determined after oven drying at $60^{\circ} \mathrm{C}$ for at least $96 \mathrm{~h}$. The detritus fraction had been previously preserved in a $4 \%$ formaldehyde buffered seawater solution. Fauna from preserved samples were sorted, and identified to the lowest taxonomic level possible. Animals from $\mathrm{W}_{2}$ were not sorted due to time constraints, so only one winter survey was considered in the epifaunal analysis.

Statistical procedures. To determine if water column variables resembled the typical conditions for phytoplankton productivity distributions (see 'Sampling design'), we performed a Principal Component Analysis (PCA) on their correlation matrix. Data transformation was not necessary. Spatial variations of the depth averaged irradiance attenuation coefficient $\left(K_{\mathrm{av}, z}\right)$ between subsurface water and upper surface of the Zostera marina leaf canopy were calculated following the simplest expression of Beer's law equation (Kirk 2003). A linear regression analysis was used to investigate relationships between $K_{\mathrm{av}, \mathrm{z}_{1} \rightarrow \mathrm{z}_{2}}$ values and seston concentration. The regression equation allowed $K_{\mathrm{av}, z}$ estimates from mean season - meadow seston of the complete time-series data. The percentage of light reaching the sediment after passing through the overlying water column was estimated applying Beer's equation and tide adjusted by adding half the diurnal tidal range to the depth of each meadow $\left(\mathrm{z}_{2}\right)$ (Koch 2001).

We assessed interactions among eelgrass, opportunistic algae with potential negative effects on eelgrass (epiphytes, macroalgae), and mesograzer taxa associated with eelgrass meadows (abundance), through a combination of multivariate techniques. As we were interested only in epifaunal taxa related to the vegetation variables, we applied a Canonical Correspondence Analysis (CCA) for a direct assessment of the relationships between both matrices through PC-ORD (McCune et al. 2002). Stepwise multiple linear regressions were run to test for specific correlations between eelgrass biomass, density, growth and other eelgrass stress sensitive variables (leaf length, root and rhizome biomass, etc.) as response variables and up to 19 potential controlling variables (predictors): plant architecture (density and biomass of vegetative and reproductive shoots, number of leaves, leaf length and width, belowground biomass), macrodetritus biomass, macroalgal biomass, epiphyte biomass per unit leaf biomass, sediment organic matter content and abundance of 8 dominant mesograzer taxa (amphipods, Paracerceis sp., Erichsonella sp., Nebalia sp., caridean shrimps, Mitrella spp., Tectura sp. and Platynereis sp.). Multiple regressions were performed by a forward selection technique with an a priori 'p-to-enter' value of 0.05 .

Differences in assemblage compositions were assessed with PERMANOVA, a computer program for permutational multivariate analysis of variance (Anderson 2005). A 2-way nested PERMANOVA was used to test for differences among meadows and seasons (all fixed), with meadow as a nested factor within season. The null hypothesis was rejected if $\mathrm{p} \leq 0.05$. Pair-wise a posteriori tests were used to identify significant differences between meadows within seasons. The Monte Carlo asymptotic $p$-value was used when a reasonable number 
of permutations was not attained (Anderson 2005). As the program does not correct for the a posteriori experiment-wise error rate, we set $\alpha=0.01$. PERMANOVA may be sensitive to differences in spread (variability) among groups, therefore the program PERMDISP was run as a test for homogeneity to determine the nature of the differences between groups (Anderson 2004).

\section{RESULTS}

Alternating patterns of abundance at successive trophic levels through the food chain were widespread within meadows more influenced by upwelling (BY and BF, Fig. 2). BY and BF water column samples were clearly discriminated from SQ by nitrate concentration and by salinity through the second principal component of the PCA (Fig. 3). Principal component 2 was negatively related to nitrate concentration $(\mathrm{r}=-0.7)$ and positively to salinity $(r=0.8)$. Nitrate concentrations were highest in BY meadow, intermediate in BF and lowest in SQ during both summer and winter (Fig. 4). Decreasing DIN concentrations from BY and BF toward SQ, DIN concentration dominated by nitrate + nitrite in BY, silicate concentration patterns (not shown), and Bakun upwelling index for the region $\left(30^{\circ} \mathrm{N}, 119^{\circ} \mathrm{W}\right.$, Pacific Fisheries Environmental Laboratory, NOAA: http://upwell.pfeg.noaa.gov), indicated that during summer and winter time-series the lagoon imported significant amounts of nitrate from the ocean, and concentrations remained relatively high through the sampling period (Fig. 4).

A classic 3 level trophic cascade pattern from small fish through to epiphytes was detected only in BF during summer (Fig. 2). However, evidence for small fish control of mesograzer abundance was found in all meadows under intermediate or high DIN availability regimes (BF and BY during both seasons, Fig. 2). Significant differ-

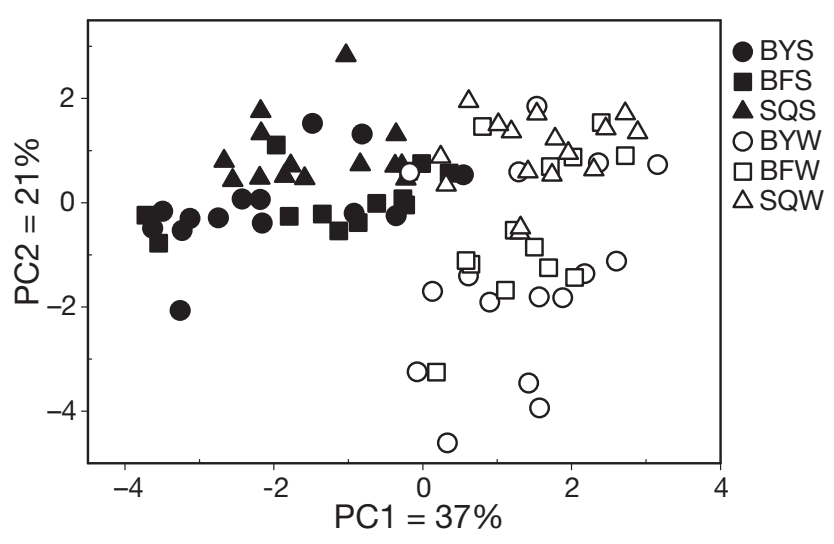

Fig. 3. Principal component analysis (PCA) of Base Y (BY), Bahia Falsa (BF) and Bahia San Quintin (SQ) water column samples. The first 2 principal components (PC 1, PC 2) explained $58 \%$ of the variance in the data $(\mathrm{N}=86)$. The third letter of sample codes (e.g. BYS) identifies season: summer $2001(\mathrm{~S})$, or winter $2002(\mathrm{~W})$

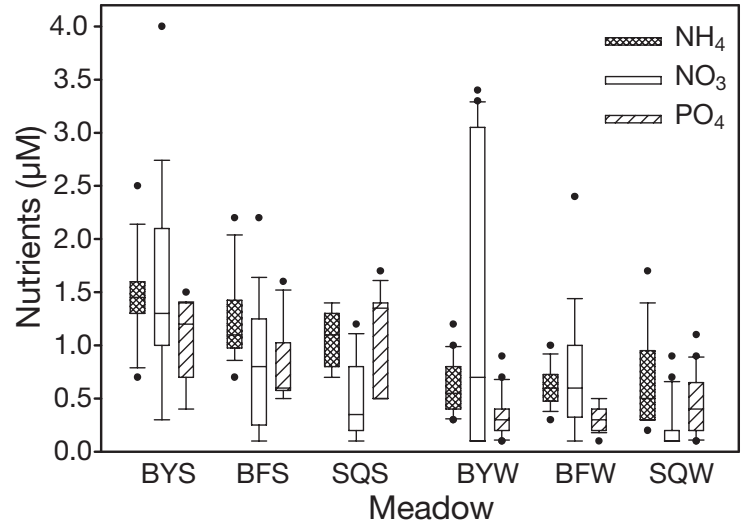

Fig. 4. Box plots of water column inorganic nutrient concentrations within Base Y (BY), Bahia Falsa (BF) and Bahia San Quintin $(\mathrm{SQ})$ meadows $(\mathrm{N}=86)$. The third letter of samples code (e.g. BYS) identifies season: summer 2001 (S), or winter 2002 (W). The boundary of the box indicates the 25th to 75th interquartile range around the median. Whiskers indicate the 10 th and 90th percentiles. Outliers are also indicated 
Table 1. Summary of 2-way nested PERMANOVA (permutational Multivariate Analysis of Variance) for differences among meadows and seasons treatments $(\alpha \leq 0.05)$

\begin{tabular}{|llrrcc|}
\hline & Source & df & MS & $F$ & $\mathrm{p}$ \\
\hline Nekton & Season & 1 & 3058 & 4.25 & 0.0030 \\
& Meadow & 4 & 3586 & 4.98 & 0.0002 \\
& Residual & 12 & 720 & & \\
& Total & 17 & & & \\
Epibenthos & Season & 1 & 5867 & 10 & 0.0001 \\
& Meadow & 4 & 7665 & 14 & 0.0001 \\
& Residual & 18 & 566 & & \\
& Total & 23 & & & \\
Vegetation & Season & 1 & 2442 & 45 & 0.0001 \\
& Meadow & 4 & 704 & 13 & 0.0001 \\
& Residual & 42 & 54 & & \\
& Total & 47 & & & \\
\hline
\end{tabular}

ences in small fish assemblage structure were greatly influenced by the dominance of the bay pipefish Syngnathus leptorhynchus (Table 1). The bay pipefish exceeded $80 \%$ of total nektonic organisms in BF and SQ in both seasons (Table 2). When bay pipefish (and hence small fish) were abundant, epifauna density was low and epiphyte biomass high (BF in summer, Fig. 2). Mesograzer abundance, however, did not relate to high bay pipefish abundance in SQ during winter (Fig. 2). When bay pipefish or small fish abundance were intermediate or low, mesograzer density peaked, and epiphyte biomass was consistently low (BY both seasons, and BF during winter, Fig. 2). Again, SQ was the exception as it showed no evidence for consumer control of lower trophic levels (SQ summer, Fig. 2).

The epifaunal assemblage composition and abundance differed significantly between seasons and

Table 2. Mean ( $\pm 1 \mathrm{SE}$ ) abundances (ind. $200 \mathrm{~m}^{-2}$ ) of the most representative nekton species in Base Y (BY), Bahia Falsa (BF) and Bahia San Quintin (SQ) meadows (n = 3)

\begin{tabular}{|c|c|c|c|c|c|c|}
\hline & \multicolumn{3}{|c|}{ Summer - } & \multirow{2}{*}{\multicolumn{2}{|c|}{$\begin{array}{c}\text { - Winter } \\
\text { BF }\end{array}$}} & \multirow[b]{2}{*}{$\mathrm{SQ}$} \\
\hline & BY & $\mathrm{BF}$ & $\mathrm{SQ}$ & & & \\
\hline Syngnathus leptorhynchus & $186(59)$ & $395(90)$ & $166(10)$ & $26(14)$ & $162(12)$ & $352(3)$ \\
\hline Hypsoblennius gentilis & $16(10)$ & $22(6)$ & $2(2)$ & $1(1)$ & $1(1)$ & $1(1)$ \\
\hline Hypsoblennius jenkinsi & $31(25)$ & $25(4)$ & $1(1)$ & $1(1)$ & $2(2)$ & $0(0)$ \\
\hline Hурегprosopon argenteum & $3(2)$ & $7(1)$ & $3(1)$ & $0(0)$ & $0(0)$ & $0(0)$ \\
\hline Cymatogaster aggregata & $4(2)$ & $14(3)$ & $2(1)$ & $0(0)$ & $0(0)$ & $0(0)$ \\
\hline Scorpaena guttata & $8(5)$ & $8(4)$ & $4(2)$ & $0(0)$ & $1(1)$ & $0(0)$ \\
\hline Paralabrax clathratus & $3(3)$ & $1(2)$ & $2(1)$ & $0(0)$ & $0(0)$ & $0(0)$ \\
\hline Paralabrax nebulifer & $2(1)$ & $1(1)$ & $2(2)$ & $0(0)$ & $0(0)$ & $0(0)$ \\
\hline Total & $271(101)$ & $490(86)$ & $187(3)$ & $69(16)$ & $183(17)$ & $362(5)$ \\
\hline
\end{tabular}

Table 3. Mean $( \pm 1 \mathrm{SE})$ abundance (ind. $\mathrm{m}^{-2}$ ) of the most representative epifaunal taxa in Base Y (BY), Bahia Falsa (BF) and Bahia San Quintin (SQ) meadows (summer: $\mathrm{n}=8$; winter: $\mathrm{n}=4$ )

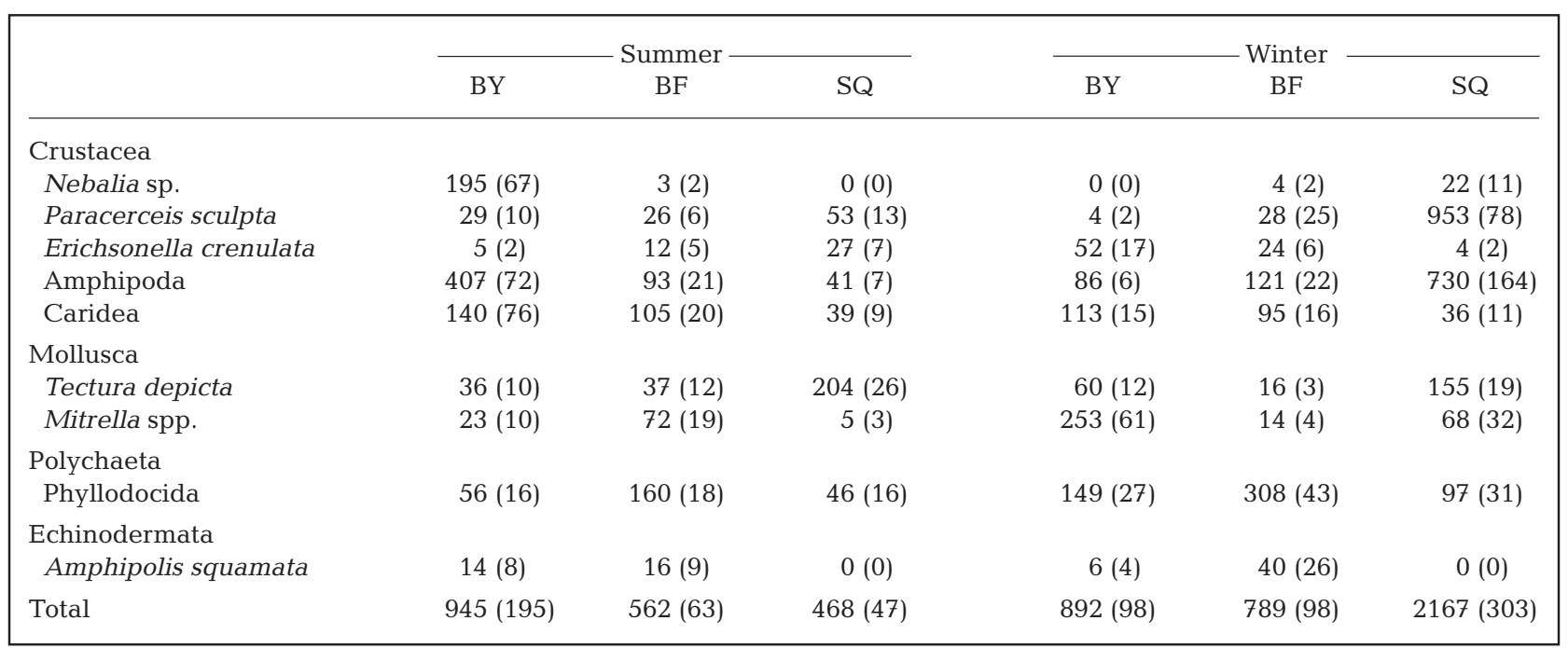




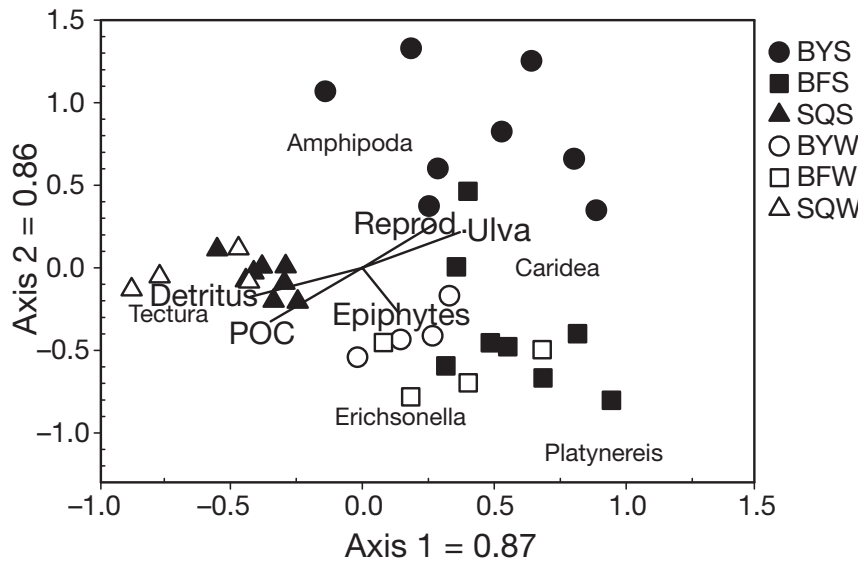

Fig. 5. Canonical correspondence analysis (CCA) ordination triplot of benthic sample unit points (meadow, shown as symbols), the vegetation components (as vectors radiating from the centroid), and epifaunal taxa (by name) within Base $Y$ (BY), Bahia Falsa (BF) and Bahia San Quintin (SQ) meadows. The third letter of samples code identifies season (e.g. BYS): summer 2001 (S), or winter 2002 (W). The length of the vegetation vectors represents the strength of trends, and the angle between pairs of vectors approximates the correlation between the respective variables. Epifaunal names within the ordination plot indicate their distribution optima. The first 2 CCA axes represented $39 \%$ of the variability in the community data. For each CCA axis, the Pearson correlation coefficient between the matrix of epifaunal taxa and the vegetation structure is indicated

among meadows within seasons (Tables $1 \& 3$ ). Differences detected were structural and not due to unequal multivariate dispersion among groups compared (PERMDISP, seasons: $p=0.0977$; meadows: $p=0.3766)$. PERMANOVA pair-wise a posteriori tests indicated significant differences between all possible comparisons in the nested design $(\mathrm{p}<0.01)$. The epifaunalvegetation ('species-environment') Pearson correlation coefficients suggested a strong relationship between 15 epifaunal taxa and the vegetation structure for the first 3 CCA axes $(0.87,0.86$ and 0.79 , respectively; Monte Carlo test, $\mathrm{p}=0.02$ ). Two numerically important mesograzer groups were differentially related to epiphyte biomass (Fig. 5). The polychaete Platynereis bicanaliculata was inversely correlated to axis 2 ( $\mathrm{r}=$ -0.6, Fig. 5), and its distribution optima were in samples with high epiphyte biomass over eelgrass leaves (Fig. 6). The isopod Erichsonella crenulata and the small gastropods Mitrella spp. (not shown) were also included in the Platynereis group (Fig. 5). Conversely, amphipod abundance was inversely related to epiphyte biomass on eelgrass leaves, and was highest during summer BY and winter SQ meadows (Figs. 5 \& 6).

The vegetation assemblage varied significantly both seasonally and spatially, although meadow comparisons were sensitive to heterogeneous variability among groups (Table 1; PERMDISP, seasons: $\mathrm{p}=$ 0.8001, meadows: $\mathrm{p}=0.0535$ ). However, PERMANOVA a posteriori tests indicated significant differences for all pair-wise meadow comparisons ( $p<0.01$; PERMDISP, $p>0.05)$, excepting BY and BF during winter (PERMANOVA, $\mathrm{p}>0.05$ ). Macroalgal biomass (> $90 \%$ Ulva expansa) was responsible for much of the structural difference in among meadows vegetation (Fig. 5; intraset correlation coefficient between $U$. expansa and the first CCA ordination axis $=0.7$ ). Ulva expansa biomass (hereafter 'Ulva') attained $90 \%$ of mean total Zostera marina aboveground biomass in BY summer, even when eelgrass reached the highest vegetative plus reproductive aboveground mean biomass in this study (Table 4), and was almost absent at the lower end of the productivity gradient, i.e. SQ. Despite high attenuation of light reaching the canopy of eutrophic meadows (Fig. 7), eelgrass was likely not affected by
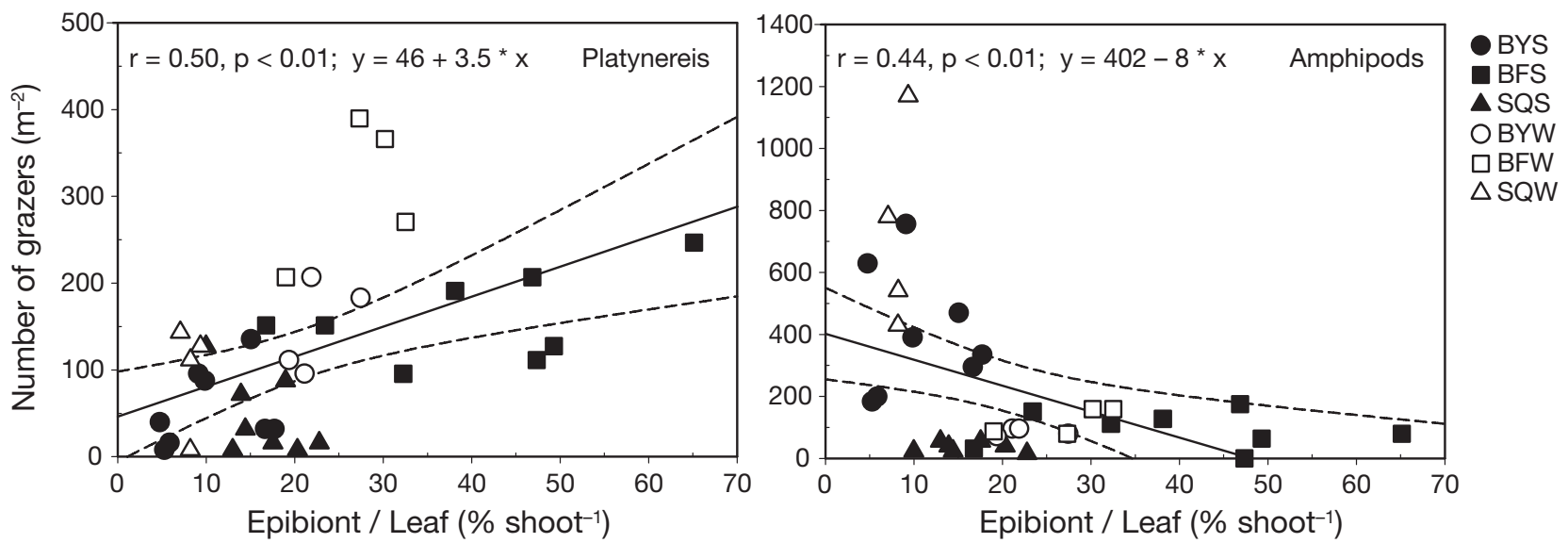

Fig. 6. Platynereis bicanaliculata and amphipods vs. Zostera marina epiphytes. Relationship between mesograzer abundances and epiphyte biomass at Base Y (BY), Bahia Falsa (BF) and Bahia San Quintin (SQ) meadows ( $\mathrm{N}=36)$. The third letter of samples code identifies season (e.g. BYS): summer 2001 (S), or winter 2002 (W). The solid line represents the regression model; dashed lines delimit $95 \%$ confidence intervals 


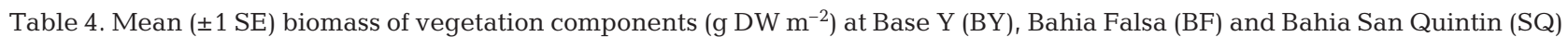
meadows $(\mathrm{n}=8)$. $\mathrm{POM}=$ percent organic matter

\begin{tabular}{|c|c|c|c|c|c|c|}
\hline & \multicolumn{3}{|c|}{ Summer } & & \multirow{2}{*}{$\begin{array}{c}\text { Winter } \\
\text { BF }\end{array}$} & \multirow[b]{2}{*}{$\mathrm{SQ}$} \\
\hline & BY & $\mathrm{BF}$ & SQ & BY & & \\
\hline Leaves & $95(22)$ & $86(20)$ & $113(19)$ & $70(6)$ & $73(11)$ & $83(13)$ \\
\hline Sheaths & $45(9)$ & $39(5)$ & $29(6)$ & $75(6)$ & $103(21)$ & $54(12)$ \\
\hline Reproductive shoots & $71(18)$ & $51(10)$ & $20(9)$ & $0(0)$ & $0(0)$ & $5(2)$ \\
\hline Rhizomes and roots & 59 (13) & $93(17)$ & $154(17)$ & $264(23)$ & $193(22)$ & $378(38)$ \\
\hline Macroalgae (Ulva sp.) & $150(25)$ & $35(10)$ & $0(0)$ & 37 (16) & $127(50)$ & $1(1)$ \\
\hline Epiphytes (\% leaves) & $11(2)$ & $40(6)$ & $16(2)$ & $17(3)$ & $19(3)$ & $6(1)$ \\
\hline Detritus & $53(18)$ & $80(14)$ & $186(18)$ & $203(84)$ & $123(20)$ & $280(37)$ \\
\hline POM (\%) & $3(0)$ & $7(1)$ & $14(1)$ & $12(0)$ & $9(1)$ & $12(1)$ \\
\hline
\end{tabular}

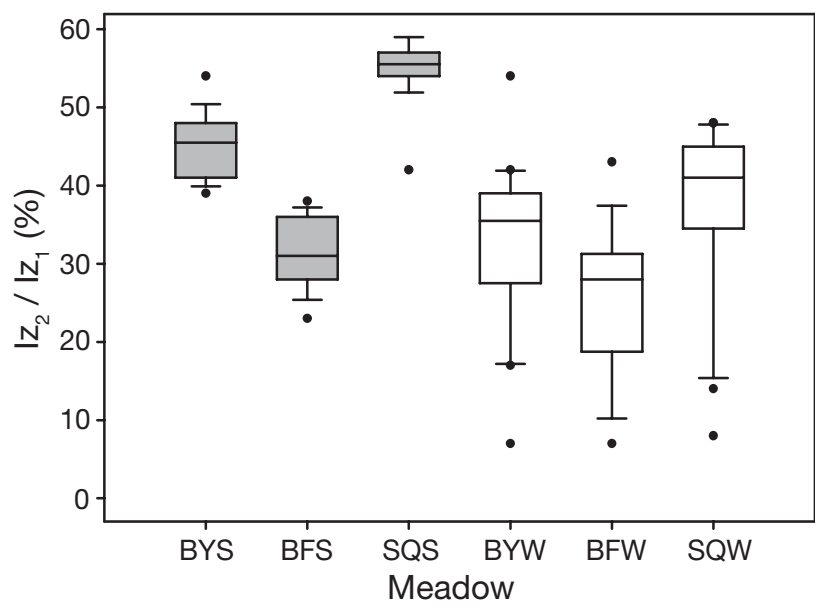

Fig. 7. Percentage of light reaching the sediment, estimated through a linear regression of $K_{\mathrm{av}, z}$ on seston $\left(K_{\mathrm{av}, z}=0.43+\right.$ $0.134 \times$ seston; $\left.\mathrm{r}^{2}=0.83, \mathrm{p}<0.01\right)$ applying Beer's equation and correcting for tidal range (see 'Statistical procedures'). The third letter of samples code identifies season (e.g. BYS): summer 2001 (S), or winter 2002 (W). The boundaries of the boxes indicates the 25th to 75 th interquartile ranges around the medians. Whiskers indicate the 10th and 90th percentiles. Outliers are also indicated; $\mathrm{N}=86$

Table 5. Zostera marina. Mean ( $\pm 1 \mathrm{SE})$ eelgrass architectural variables at Base $\mathrm{Y}$ (BY), Bahia Falsa (BF) and Bahia San Quintin (SQ) meadows $(\mathrm{n}=8)$

\begin{tabular}{|c|c|c|c|c|c|}
\hline & \multicolumn{3}{|c|}{ Leaf variables } & \multicolumn{2}{|c|}{ Density variables } \\
\hline & $\begin{array}{l}\text { Number } \\
\left(\text { shoot }^{-1}\right)\end{array}$ & $\begin{array}{c}\text { Length } \\
\left(\mathrm{mm} \mathrm{leaf}^{-1}\right)\end{array}$ & $\begin{array}{l}\text { Width } \\
\text { (mm) }\end{array}$ & $\begin{array}{l}\text { Vegetative } \\
\text { shoots } \\
\left(\text { shoots } \mathrm{m}^{-2}\right)\end{array}$ & $\begin{array}{c}\text { Reproductive } \\
\text { shoots } \\
\left(\text { shoots } \mathrm{m}^{-2} \text { ) }\right.\end{array}$ \\
\hline \multicolumn{6}{|c|}{ Summer } \\
\hline BY & $3.8(0.1)$ & $363(20)$ & $5.6(0.2)$ & $506(76)$ & $142(26)$ \\
\hline $\mathrm{BF}$ & $3.5(0.2)$ & $443(36)$ & $6.3(0.3)$ & $288(47)$ & $99(17)$ \\
\hline SQ & $3.8(0.1)$ & $363(31)$ & $5.5(0.1)$ & $440(52)$ & $33(11)$ \\
\hline \multicolumn{6}{|c|}{ Winter } \\
\hline BY & $5.3(0.2)$ & $272(10)$ & $5.4(0.0)$ & $560(64)$ & $0(0)$ \\
\hline $\mathrm{BF}$ & $4.9(0.3)$ & 269 (13) & $5.7(0.2)$ & $476(57)$ & $0(0)$ \\
\hline SQ & $4.9(0.2)$ & $148(6)$ & $4.2(0.1)$ & 1024 (239) & $34(14)$ \\
\hline
\end{tabular}

drifting mats of the macroalgae $(-0.3<\mathrm{r}<0.3$; $\mathrm{p}>$ 0.05). Furthermore, neither of the eelgrass architectural descriptors shown in Table 5 was significantly correlated with Ulva biomass ( $p>0.05$ ). Vegetative eelgrass shoot density, however, was inversely related to epiphyte biomass on eelgrass leaves $(\mathrm{r}=-0.32 ; \mathrm{p}=$ 0.0266).

Differences in density and growth rates of vegetative eelgrass shoots among meadows explained productivity variability patterns at the bottom of the food chains (eelgrass, Fig. 2). Eelgrass growth rates were lower in the SQ meadow despite reduced epiphyte biomass and higher light availability ( $\mathrm{p}<0.05$, Table 6). A forward stepwise multiple regression analysis restricted to $\mathrm{S}_{2}$ samples $(\mathrm{N}=12)$ indicated that eelgrass growth biomass was very well described by only 3 independent variables. The densities of the acmeid limpet Tectura depicta and the isopod Erichsonella crenulata, and eelgrass leaf length accounted for most of the variability in the growth of Zostera $\left(\mathrm{R}^{2}=0.80 ; \mathrm{p}=0.0036\right)$. The density of $T$. depicta was inversely correlated with eelgrass growth (partial correlation $=-0.79 ; \mathrm{p}=0.0061$ ) (Fig. 8), while E. crenulata showed a positive relationship with the response variable (part. correl. $=0.69 ; \mathrm{p}=0.0278)$. Eelgrass growth was also directly related to leaf length (part. correl. $=0.67 ; \mathrm{p}=0.0338$ ). The regression model accounted for a greater proportion of Zostera growth variability when expressed as length $\left(\mathrm{R}^{2}=0.97 ; \mathrm{p}=0.0001\right)$. However, 5 independent variables significantly contributed to the model. Novel to the model was living belowground biomass, which seems to positively affect eelgrass growth (part. correl. $=0.75 ; \mathrm{p}=$ 0.0316); sediment organic matter content was inversely correlated to the response variable (part. correl. $=-0.88$; $\mathrm{p}=0.0041$ ). 
Table 6. Zostera marina. Mean $( \pm 1 \mathrm{SE})$ eelgrass growth at Base Y (BY), Bahia Falsa (BF) and Bahia San Quintin (SQ) meadows $(n=4)$

\begin{tabular}{|lcc|}
\hline & $\begin{array}{c}\text { Length } \\
\left(\mathrm{cm} \mathrm{d}^{-1} \text { shoot }^{-1}\right)\end{array}$ & $\begin{array}{c}\text { Weight } \\
\left(\mathrm{mg} \mathrm{d}^{-1} \text { shoot }^{-1}\right)\end{array}$ \\
\hline Summer & & \\
BY & $3.5(0.5)$ & $5.9(1.4)$ \\
BF & $3.9(0.7)$ & $9.1(2.3)$ \\
SQ & $2.3(0.2)$ & $4.2(1.1)$ \\
Winter & & \\
BY & $4.3(0.2)$ & $6.0(0.4)$ \\
BF & $4.7(0.4)$ & $7.0(0.6)$ \\
SQ & $2.3(0.2)$ & $2.2(0.2)$ \\
\hline
\end{tabular}

\section{DISCUSSION}

Inferences about the outcome of interactions among trophic levels (or functional groups) from patterns of abundance in this study indicated strong top-down control of eelgrass communities. Bottom-up processes, however, may significantly influence the relationship between functional groups. We found ubiquitous support for mesograzer control of epiphyte biomass over a relatively wide range of water column nutrient concentrations and productivity regimes (Fig. 9). Epiphyte biomass was inversely related to population densities of mesograzers, and was unlikely to have been determined only by nutrient availability. This result was particularly noticeable under eutrophic conditions, and its hence inconsistent with deterministic bottom-up models that predict accrual of opportunistic epiphytes on seagrass blades with nutrient enrichment (e.g. Duarte 1995). While some field studies have revealed positive relations between nutrients and epiphyte biomass (references in Duarte 1995), we did not observe such a trend. Epiphyte biomass over eelgrass blades was highest in the BF meadow during summer, but low in BY where nutrient concentration peaked (Fig. 2). Manipulations of both nutrient loading and mesograzers abundance have demonstrated that epiphyte abundance is not determined by nutrient availability, but is governed by population densities of mesograzers (e.g. Heck et al. 2000).

Epiphyte biomass control by invertebrate grazing has widely recognized beneficial effects on seagrasses. Mesograzers indirectly enhance plant fitness by reducing epiphyte biomass where, other-

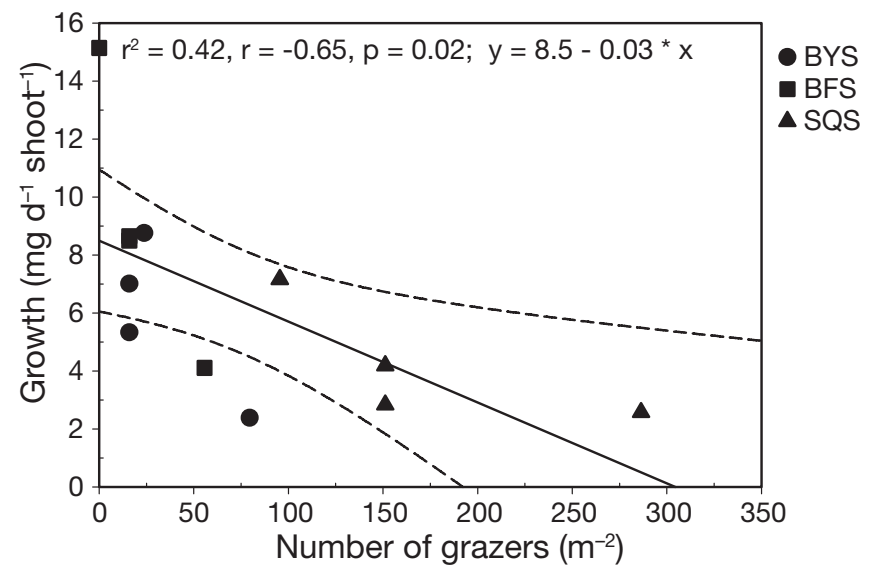

Fig. 8. Zostera marina vs. Tectura depicta. Relationship between eelgrass growth rates and limpet abundances during summer at Base Y (BYS), Bahia Falsa (BFS) and Bahia San Quintin (SQS) meadows $(\mathrm{N}=12)$. The solid line represents the regression model; dotted lines delimit $95 \%$ confidence intervals

wise, nutrient availability would favor superior competitive epiphytes over seagrass (Hughes et al. 2004). However, in our study, small fish in BF during summer likely influenced mesograzer abundance and potentially affected the outcome of competitive interactions between epiphytes and seagrass through a trophic cascade (Figs. 2 \& 9). Patterns of total abundance or biomass at the mesograzer and epiphyte levels in BF during summer were consistent with destabilizing trophic cascade model predictions when small fish were abundant (of which $\sim 80 \%$ were bay pipefish Syngnathus lepto-

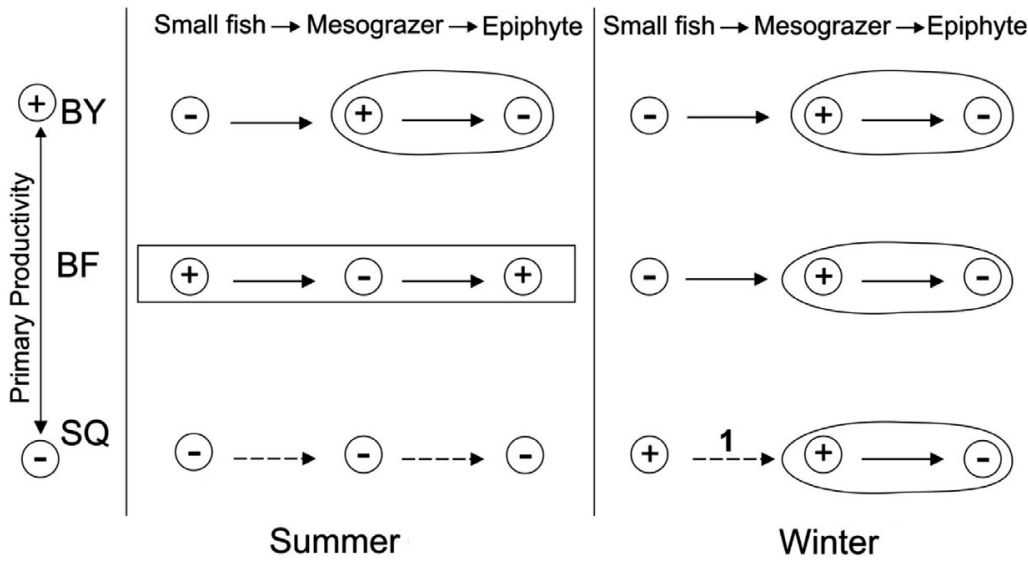

Fig. 9. Trophic interaction diagram inferred from patterns of density (or biomass) through the 3 food chain trophic levels at Base Y (BY), Bahia Falsa $(\mathrm{BF})$ and Bahia San Quintin (SQ) meadows. Continuous arrows indicate negative strong trophic interactions, while dashed arrows indicate weak interactions. $(+)$ or $(-)$ signs indicate high or low abundance, respectively. The rectangle frames the alternation of high and low densities (or biomasses) between successive trophic levels, consistent with the trophic cascade model; ovals highlight strong mesograzer control over epiphyte biomass. 1: mesograzer size-refuge from juvenile pipefish 
rhynchus), habitat complexity was relatively low (i.e. total Ulva + Zostera aboveground biomass), and nutrient availability was high. Furthermore, evidence of topdown control through alternating patterns of abundance at successive trophic levels in the remaining eutrophic meadows suggests that bay pipefish abundance ultimately governs the success of eelgrass meadows (BY summer and BY and BF in winter, Figs. 2 \& 9). Comparable destabilizing cascades involving strong links between small fish predators, invertebrate grazers, and rooted plants and epiphytes are evident in vegetated shallow lakes (Jones \& Sayer 2003).

Seagrass confers a complex habitat that reduces the predation effectiveness of many consumers (reviewed in Heck \& Orth 2006), but may not affect the foraging rate of syngnathids fish (James \& Heck 1994). This is because syngnathid appear to adjust foraging tactics in response to changes in habitat complexity (Ryer 1988, James \& Heck 1994). Syngnathids are particularly efficient mesograzer predators, and the bay pipefish is no an exception (P. Jorgensen unpubl. data). During this study, a mean density of $\sim 2$ bay pipefish $\mathrm{m}^{-2}$ probably exerted an intense predation pressure on amphipods and other mesograzers populations during summer, promoting epiphyte accumulation over eelgrass leaves. The alternating patterns of abundance between bay pipefish, mesograzers and epiphytes are indicative of the potential role of syngnathids as keystone predators in seagrass systems, and inconsistent with bottom-up control of mesograzers populations (Fig. 9). However, predation pressure does not seem to affect total mesograzer abundance at SQW, despite high bay pipefish densities. The pipefish population at SQW was characterized by a disproportionately high dominance of juveniles (median $=75 \mathrm{~mm} ; \mathrm{N}=1057 ; 75 \%$ of $\mathrm{N}<93 \mathrm{~mm}$, P. Jorgensen unpubl. data), which must have been gap-limited for feeding on large body amphipods and isopods, such as Paracerceis sculpta (see Ryer 1988, and references therein). Hence, mesograzers at SQW probably achieved a size-refuge in which they were invulnerable to predation (Fig. 9).

High biomass of Ulva may have also explained spatial differences in mesograzer densities during summer, by reducing predation pressure on epifauna. At the higher end of the natural fertilization gradient, BY, Ulva biomass averaged $150 \mathrm{~g}$ dry wt $\mathrm{m}^{-2}$ and sustained an abundant and diverse epifaunal community. Under intermediate fertilization conditions, BF, Ulva biomass attained a biomass amounting to $23 \%$ of that in BY, and epifaunal abundance was low. The foliose thallus of Ulva can provide epifauna with additional physical structure when stacked in many layers (Parker et al. 2001) and impose greater visual interference than narrower eelgrass leaves, thus decreasing the susceptibility of prey to visual predators, such as pipefish (see
Ryer 1988). Interestingly, amphipod density in BFS was lower than that in BYS (by about about the same proportion as the reduction in Ulva density).

Ulvoids are more widely recognized by their direct reduction in seagrass fitness through overshading, oxygen depletion or toxic ammonium concentrations (e.g. Cummins et al. 2004), than for their indirect positive effects through epiphyte reduction. Light estimations on the bottom directly below a macroalgal mat indicate that it may attenuate $\sim 90 \%$ of incoming light (Brush \& Nixon 2003). In San Quintin Bay, Ulva expansa within eelgrass meadows can form thalli up to $2 \mathrm{~m}$ in diameter (Jorgensen pers. obs.), whereas individual patches reached $\sim 350 \mathrm{~g}$ dry $\mathrm{wt}^{-2}$. Comparable ulvoid mats have been shown to reduce Zostera growth, shoot density or biomass in areas lacking significant anthropogenic eutrophication in the northeastern Pacific (Nelson et al. 2003, and references therein).

Despite the potential light limitation for Zostera in eutrophic meadows, neither eelgrass shoot growth nor aboveground biomass were related to $K_{\mathrm{av}, \mathrm{z}}$, the amount of drifting Ulva, or epiphyte biomass over eelgrass leaves. To some extent, eelgrass may adapt biochemically and morphologically to unfavourable conditions and thereby buffer changes in measured parameters (Greve \& Krause-Jensen 2005). Allocation of photosynthetic carbon fixation to leaf production and elongation at the expense of belowground structure is usually one of the first signs of seagrass stress. A greater leaf length and lower shoot density and belowground biomass in BF during summer (Table 5) may indicate compensation for low light levels (see references in Greve \& Krause-Jensen 2005). Vegetative shoot density was inversely related to epiphyte biomass on eelgrass leaves, indicating potential competitive interactions for available light between eelgrass and its epiphytes. Incident light attenuation by the epiphyte complex biomass at BF summer meadow (= $1.3 \mathrm{mg} \mathrm{DW} \mathrm{cm}^{-2}$ ) ranged from 26 to $56 \%$, as estimated by applying 2 regression models for Zostera marina (see references in Brush \& Nixon 2002). Similar epiphyte light attenuation percentages reduced eelgrass leaf photosynthesis by $49 \%$ in Monterey Bay (Drake et al. 2003).

Opportunistic algae are likely nutrient limited in SQ. Ulva was almost absent during both sampling seasons, and epiphyte biomass was relatively low, despite the lowest mesograzer abundance estimated during summer throughout the study. Eelgrass probably compensated for nutrient limitation by increasing root surface area to facilitate nutrient uptake (see Lee \& Dunton 1999). Thus, eelgrass contribution to SQ food web should be proportionately more important than in more eutrophic meadows (see McClelland \& Valiela 1998). During summer, mesograzer community struc- 
ture was dominated by Tectura depicta, an acmeid limpet that grazes eelgrass leaf epidermis and has dramatic impacts on eelgrass production and biomass, even under a favorable light environment (Zimmerman et al. 2001). We estimated a $\sim 50 \%$ reduction in eelgrass growth by a limpet density of 200 ind. $\mathrm{m}^{-2}$, in comparison to meadows without limpets (Fig. 8). This strongly antagonistic relationship between eelgrass growth and $T$. depicta abundance is consistent with predictions of increasing importance of direct consumption on macrophyte tissue when low nutrient concentration limits algal development (Hay et al. 2004, Valentine \& Duffy 2006).

Benthic algae (e.g. epiphytes, macroalgae) have a primary trophic role as sources of organic matter for consumers in modern seagrass communities (McClelland \& Valiela 1998). This role is explained by their high biomass-specific primary production rates, and higher nutritional quality (i.e. relatively rich $\mathrm{N}$ and low structural carbohydrates content) compared to seagrass. Thus it is likely that eelgrass meadows subsidized through upwelling events with labile organic matter and nitrate loading have increased benthic algal productivity, predation rates and energy transfer upward through the food web. Similar positive linkages between bottom-up and top-down processes have been described in rocky intertidal communities, where major spatial differences in community structure and dynamics are driven by oceanographic subsidy variability (Menge et al. 1997). Hence, it is likely that the trophic structure of meadows at the lower end of the productivity gradient (i.e. less affected by coastal upwelling) may be explained by weaker predator control of mesograzer populations associated with reduced bottom-up processes.

In conclusion, our results emphasize the importance of a positive feedback mechanism between mesograzers and eelgrass under which mesograzers would enhance eelgrass growth by removing epiphytes, while the structurally complex seagrass habitat diminishes predation pressure on epifauna. Small predators, such as pipefish, that are well adapted to forage within the tangle of seagrass leaves may influence mesograzer abundance and potentially affect the outcome of competitive interactions between epiphytes and seagrass through a destabilizing trophic cascade. Trophic cascades leading to eelgrass reduction would usually be dampened by functional ecosystem mechanisms and physiological adaptation under light limitation conditions that confer seagrass systems the ability to withstand perturbations without marked changes in composition. However, evidence supporting a trophic cascade pattern may indicate susceptibility of the system to switches in water transparency (from a clear water state dominated by slow growing macrophytes (i.e. seagrass) to a turbid state dominated by phytoplankton or macroalgae). In seagrass ecosystems where algal productivity may be constrained by bottom-up processes, indirect trophic effects through epiphyte grazing should be less important to ecosystem function. However, top-down processes may still control seagrass productivity as direct consumption of seagrass tissue by mesograzers must be high.

Acknowledgements. We are grateful to P. Castro, O. González, V. Guerrero, C. Hereu, J. Hernández, J. Mariscal-Medina, R. Munch, and numerous students from CET-MAR (Ensenada) for field and laboratory assistance. Agromarinos and the Old Mill Hotel for logistic support in the field. J.A. Rosales-Casián and G. Villarreal assisted with identification of fish and epifauna, respectively. S.V. Smith (CICESE), D. Talley (UC Davis), and 2 anonymous reviewers greatly improved the manuscript. E. Carrera (Ducks Unlimited Mexico) provided the Landsat-5 TM image used to prepare Fig. 1. J.M. Domínguez and F.J. Ponce assisted with Figs. 1 \& 9. P.J. was supported by a scholarship from SRE-CONACYT-OEA (Mexico), a complement from CICESE and SIMAC, and own resources. Research funding was provided by SIMAC (grant 7013), CONACYT (grant 25030-T), and UABC (grant 4041).

\section{LITERATURE CITED}

Alvarez-Borrego S (2004) Nutrient and phytoplankton dynamics in a coastal lagoon strongly affected by coastal upwelling. Cienc Mar 30:1-19

Anderson MJ (2004) PERMDISP: A FORTRAN computer program for permutational analysis of multivariate dispersions (for any 2-factor ANOVA design) using permutation tests. Department of Statistics, University of Auckland, Auckland, New Zealand

Anderson MJ (2005) PERMANOVA: A FORTRAN computer program for permutational multivariate analysis of variance. Department of Statistics, University of Auckland, Auckland, New Zealand

Attrill MJ, Strong JA, Rowden AA (2000) Are macroinvertebrate communities influenced by seagrass structural complexity? Ecography 23:114-121

Brush MJ, Nixon SW (2002) Direct measurements of light attenuation by epiphytes on eelgrass Zostera marina. Mar Ecol Prog Ser 238:73-79

Brush MJ, Nixon SW (2003) Biomass layering and metabolism in mats of the macroalga Ulva lactuca L. Estuaries 26: 916-926

Camacho-Ibar VF, Carriquiry JD, Smith SV (2003) Non-conservative $\mathrm{P}$ and $\mathrm{N}$ fluxes and net ecosystem production in San Quintin Bay, México. Estuaries 26:1220-1237

Cummins SP, Roberts DE, Zimmerman KD (2004) Effects of the green macroalga Enteromorpha intestinalis on macrobenthic and seagrass assemblages in a shallow coastal estuary. Mar Ecol Prog Ser 266:77-87

Drake LA, Dobbs FC, Zimmerman RC (2003) Effects of epiphyte load on optical properties and photosynthetic potential of the seagrasses Thalassia testudinum Banks ex König and Zostera marina L. Limnol Oceanogr 48: 456-463

Duarte CM (1995) Submerged aquatic vegetation in relation to different nutrition regimes. Ophelia 41:87-112

Duffy JE (2006) Biodiversity and the functioning of seagrass ecosystems. Mar Ecol Prog Ser 311:233-250 
Duffy JE, Richardson JP, France KE (2005) Ecosystem consequences of diversity depend on food chain length in estuarine vegetation. Ecol Lett 8:301-309

Estes JA, Duggins D (1995) Sea otters and kelp forests in Alaska. Ecol Monogr 65:75-100

Greve TM, Krause-Jensen D (2005) Stability of eelgrass (Zostera marina L.) depth limits: Influence of habitat type. Mar Biol 147:803-812

Hairston NG, Hairston NG Jr (1993) Cause-effect relationships in energy flow, trophic structure and interspecific interactions. Am Nat 142:379-411

Hay ME, Parker JD, Burkepile DE, Caudill CC, Wilson AE, Hallinan ZP, Chequer AD (2004) Mutualisms and aquatic community structure: the enemy of my enemy is my friend. Ann Rev Ecol Syst 35:175-197

Heck KL, Jr, Orth RJ (2006) Predation in seagrass beds. In: Larkum AWD, Orth RJ, Duarte CM (eds) Seagrass: biology, ecology and conservation. Springer, Dordrecht, p 537-550

Heck KL Jr, Valentine JF (2006) Plant-herbivore interactions in seagrass meadows. J Exp Mar Biol Ecol 330:420-436

Heck KL Jr, Pennock JR, Valentine JF, Coen LD, Sklenar SA (2000) Effects of nutrient enrichment and small predator density on seagrass ecosystems: an experimental assessment. Limnol Oceanogr 45:1041-1057

Hughes AR, Bando KJ, Rodriguez LF, Williams SL (2004) Relative effects of grazers and nutrients on seagrasses: a meta-analysis approach. Mar Ecol Prog Ser 282:87-99

Ibarra-Obando SE, Aguilar-Rosas R (1985) Drift and epiphytic macroalgae associated with Zostera marina L. in San Quintin Bay (B.C., Mexico) during summer-autumn 1982: biomass and taxonomic composition. Cienc Mar 11:89-104

Ibarra-Obando SE, Smith SV, Poumian-Tapia M, CamachoIbar VF, Carriquiry JD, Montes-Hugo MA (2004) Benthic metabolism in San Quintin Bay, Baja California, Mexico. Mar Ecol Prog Ser 283:99-112

James PL, Heck KL Jr (1994) The effect of habitat complexity and light intensity on ambush predation within a simulated seagrass habitat. J Exp Mar Biol Ecol 176:187-200

Jones JI, Sayer CD (2003) Does the fish-invertebrate-periphyton cascade precipitate plant loss in shallow lakes? Ecology 84:2155-2167

Kirk JTO (2003) The vertical attenuation of irradiance as a function of the optical properties of the water. Limnol Oceanogr 48:9-17

Koch EW (2001) Beyond light: Physical, geological, and geochemical parameters as possible submersed aquatic vegetation habitat requirements. Estuaries 24:1-17

Lee K-S, Dunton KH (1999) Influence of sediment nitrogenavailability on carbon and nitrogen dynamics in the seagrass Thalassia testudinum. Mar Biol 134:217-226

McClelland JW, Valiela I (1998) Changes in food web structure under the influence on increased anthropogenic nitrogen inputs to estuaries. Mar Ecol Prog Ser 168: $259-271$

Editorial responsibility: Kenneth Heck (Contributing Editor), Dauphin Island, Alabama, USA
McCune B, Grace JB, Urban DL (2002) Analysis of ecological communities. MjM Software Design, Gleneden Beach, Oregon

Menge BA, Daley BA, Wheeler PA, Dahlhoff EP, Sanford E, Strub PT (1997) Benthic-pelagic links and rocky intertidal communities: Bottom-up effects on top-down control? Proc Nat Acad Sci USA 94:14530-14535

Nelson TA, Nelson AV, Tjoelker M (2003) Seasonal and spatial patterns of 'green tides' (Ulvoid algal blooms) and related water quality parameters in the coastal waters of Washington state, USA. Bot Mar 46:263-275

Parker JD, Duffy JE, Orth RJ (2001) Plant species diversity and composition: Experimental effects on marine epifaunal assemblages. Mar Ecol Prog Ser 224:55-67

Poumian-Tapia M, Ibarra-Obando SE (1999) Demography and biomass of the seagrass Zostera marina in a Mexican coastal lagoon. Estuaries 22:879-889

Quiroz-Vázquez P, Ibarra-Obando SE, Meling-López AE (2005) Composition of the epifaunal community associated with the seagrass Zostera marina in San Quintin Bay, Baja California. Bull Southern Calififornia Acad Sci 104: $100-112$

Ryer CH (1988) Pipefish foraging: effects of fish size, prey size and altered habitat complexity. Mar Ecol Prog Ser 48: $37-45$

Short FT, Duarte CM (2002) Methods for the measurement of seagrass growth and production. In: Short FT, Coles RG (eds) Global seagrass research methods. Elsevier, New York, p 155-182

Shurin JB, Borer ET, Seabloom EW, Anderson K, Blanchette CA, Broitman B, Cooper SD, Halpern BS (2002) A crossecosystem comparison of the strength of trophic cascades. Ecol Lett 5:785-791

Silliman BR, Bertness MD (2002) A trophic cascade regulates salt marsh primary production. Proc Nat Acad Sci USA 99: 10500-10505

Siqueiros-Beltrones DA, Ibarra-Obando SE, Loya-Salinas DH (1985) Una aproximación a la estructura florística de las diatomeas epífitas de Zostera marina y sus variaciones temporales, en Bahía Falsa, San Quintín, B.C. Cienc Mar 11: 69-88

Valentine JW, Duffy JE (2006) The central role of grazing in seagrass ecology. In: Larkum AWD, Orth RJ, Duarte CM (eds) Seagrasses: biology, ecology and conservation. Springer, Dordrecht, p 463-501

Ward DH, Morton A, Tibbitts TL, Douglas DC, CarreraGonzález E (2003) Long-term change in eelgrass distribution at Bahía San Quintín, Baja California, Mexico, using satellite imagery. Estuaries 26:1529-1539

Zimmerman RC, Steller DL, Kohrs DG, Alberte RS (2001) Topdown impact through a bottom-up mechanism. in situ effects of limpet grazing on growth, light requirements and survival of Zostera marina L. (eelgrass). Mar Ecol Prog Ser 218:127-140

Submitted: December 20, 2005; Accepted: August 7, 2006

Proofs received from author(s): February 16, 2007 